\title{
Virological Profile of Patients Infected with HIV Starting Antiretroviral Treatment in Kinshasa
}

\author{
Erick Ntambwe Kamangu ${ }^{1,2 *}$, Ben Ilunga Bulanda², Berry Ikolango Bongenia2, \\ Huguette Tshweka Botomwito², Georges Lelo Mvumbi' ${ }^{1}$, Patrick De $\mathrm{Mol}^{3}$, Dolores Vaira4, \\ Marie-Pierre Hayette ${ }^{3}$, Richard Lunganza Kalala1 \\ ${ }^{1}$ Molecular Biology Unit, Department of Basic Sciences, Faculty of Medicine, University of Kinshasa (UNIKIN), \\ Kinshasa, Democratic Republic of Congo (DRC) \\ ${ }^{2}$ Research Group "Focus HIV/AIDS”, Kinshasa, Democratic Republic of Congo (DRC) \\ ${ }^{3}$ Clinical Microbiology Laboratory, Centre Hospitalier Universitaire-Université de Liège (CHU-Lg), Liège, Belgium \\ ${ }^{4}$ AIDS Reference Laboratory (ARL), Centre Hospitalier Universitaire-Université de Liège (CHU-Lg), Liège, Belgium \\ Email: " erick.kamangu@unikin.ac.cd, erickamangu@gmail.com
}

Received 17 May 2015; accepted 1 June 2015; published 8 June 2015

Copyright (C) 2015 by authors and OALib.

This work is licensed under the Creative Commons Attribution International License (CC BY). http://creativecommons.org/licenses/by/4.0/

(C) (i) Open Access

\begin{abstract}
Background: Viral Load (VL), CD4 T cells count and clinical signs are significant parameters for the decision of starting ARV Treatment (ART). The aim of this study is to determine the Viral Load profile of eligible patients on treatment in the centers according to the algorithm used in Kinshasa and the DRC. Methodology: Our sample consisted of 153 HIV-positive patients naïve of ART. All patients aged over 18 years were included in the study without gender discrimination. The determination of the VL was made at the laboratory of Molecular Biology of the Faculty of Medicine of the University of Kinshasa using a previously described technique. Results: Of the 153 patients included in the study, $92(60.1 \%)$ were women. The age of the patients was in the range $18-65$ years with a mean of 37 years. Most patients $(91.5 \%)$ were clinical stage 3 , while the rest (8.5\%) were clinical stage 4 for HIV infection. The rates of CD4+ T lymphocytes were between 8 and 915 cells $/ \mathrm{mm}^{3}$ with a median value of 180 cells $/ \mathrm{mm}^{3}$. Seventy nine patients $(86.8 \%)$ had CD4 count below 500 cells $/ \mathrm{mm}^{3}$. The median VL of patients is $5.68 \log _{10} \mathrm{RNA}$ copies $/ \mathrm{ml}$. The minimum and maximum values are respectively 0.37 and $7.95 \log _{10}$ RNA copies $/ \mathrm{ml}$. Conclusion: The majority of patients $(63.4 \%)$ in Kinshasa begin antiretroviral treatment with a poor prognosis. The Viral loads are usually very high in these patients and CD4 quite collapsed. Indeed, the median value of CD4 for the patients is 180 cells $/ \mathrm{mm}^{3}$ for the population, while the mean value of Viral Load is 5.48 $\log _{10}$ RNA copies/ml.
\end{abstract}

\section{Keywords}

Viral Load, CD4 T Cells, Patients Eligible for Treatment, ART

${ }^{*}$ Corresponding author.

How to cite this paper: Kamangu, E.N., Bulanda, B.I., Bongenia, B.I., Botomwito, H.T., Mvumbi, G.L., De Mol, P., Vaira, D., Hayette, M.-P. and Kalala, R.L. (2015) Virological Profile of Patients Infected with HIV Starting Antiretroviral Treatment in Kinshasa. Open Access Library Journal, 2: e1564. http://dx.doi.org/10.4236/oalib.1101564 


\section{Introduction}

Thirty years after its appearance, the epidemic in Human Immunodeficiency Virus (HIV) infection remains a major public health problem. In the Democratic Republic of Congo (DRC), the first case of Acquired Immune Deficiency Syndrome (AIDS) was documented in 1983 [1]. In recent years, HIV prevalence has remained more or less stable at less than $5 \%$ [1].

Immunological criteria for initiating treatment with antiretroviral drugs (ARVs) have been revised by the National Program for the Fight against HIV/AIDS. According to the recommendations of the World Health Organization (WHO), the cut-off for CD4 T cells increased from $\leq 200$ cells $/ \mathrm{mm}^{3}$ in 2006 to $\leq 350$ cells $/ \mathrm{mm}^{3}$ in 2008 , and then to $\leq 500$ cells $/ \mathrm{mm}^{3}$ in 2013 [2]. The clinical criteria used in the DRC are those recommended by WHO for countries with limited resources [2] [3]. They depend on the interpretation of clinical parameters and WHO recommendations by the clinician.

The Viral Load (VL), CD4 T cells count and clinical signs are significant parameters for the decision to start ARV treatment (ART) [4]. The VL is as important in epidemiological surveillance, diagnosis of children under 18 months, and adherence to treatment at the change of line of treatment [4]-[6]. However, the WHO guidelines for resource-limited countries only advocate the CD4 count and clinical stages 3 and 4 to set on ART [3], and VL is not recommended for these countries because of the exorbitant cost [4] [7].

This study aims to determine the profile of Viral Load of eligible patients on treatment in the centers according to the algorithm used in Kinshasa and DRC by using the VL.

\section{Methodology}

This study was conducted in collaboration with different centers of treatment centers and monitoring of people living with HIV (PLHIV) in Kinshasa. Our sample consisted of 153 HIV-positive treatment-naive patients Antiretroviral (ART). All patients aged over 18 years were included in the study without gender discrimination. The patients were considered eligible for treatment in the different centers.

The determination of Viral Load (VL) was made in the laboratory of Molecular Biology of the Faculty of Medicine University of Kinshasa (UNIKIN) using a previously described in-house assay from $140 \mu 1$ of plasma extracted from $5 \mathrm{ml}$ of whole blood collected in a tube with anticoagulant EDTA [8] [9]. The VL results are presented as logarithm of 10 copies of RNA per ml. All the PCR were done in triplet and only the mean value were recorded. The count of CD4+ lymphocytes was done by flow cytometry and the results are presented as number of cells per $\mathrm{mm}^{3}$.

Socio-demographic information as well as clinical and laboratory parameters were recorded from patient charts from the respective centers. They were confidentially kept in the centers.

\section{Results}

\subsection{Epidemiological Data}

Of the 153 patients included in this study, $92(60.1 \%)$ patients were women and $63(39.9 \%)$ men, resulting in a sex ratio $\mathrm{M} / \mathrm{F}$ was 0.68 . The age of patients is in the range 18 to 65 years with a mean of 37 years. Table 1 presents the epidemiological data with respect to gender and age groups.

\subsection{Clinical and Biological Data}

According to the WHO classifications, most of the patients $(n=140 ; 91.5 \%)$ were in clinical stage 3 while the rest $(\mathrm{n}=13 ; 8.5 \%)$ is in clinical stage 4 for the HIV.AIDS infection. The rates of CD4 + T lymphocytes were between 8 and 915 cells $/ \mathrm{mm}^{3}$ with a median value of $180 \mathrm{cells} / \mathrm{mm}^{3}$. Seventy nine patients $(86.8 \%)$ had a CD4 count below 500 cells $/ \mathrm{mm}^{3}$. The median Viral Loads (VL) of the included patients was $5.48 \log _{10}$ RNA copies $/ \mathrm{ml}$. The minimum and maximum values for the VLs were respectively $0.37 \log _{10}$ and $7.95 \log _{10}$ RNA copies $/ \mathrm{ml}$. Ninety-seven patients (63.4\%) had a VL exceeds 100,000 RNA copies $/ \mathrm{ml}$ or $5.0 \log _{10}$ RNA copies $/ \mathrm{ml}$; 
Table 1. Characteristics of patients.

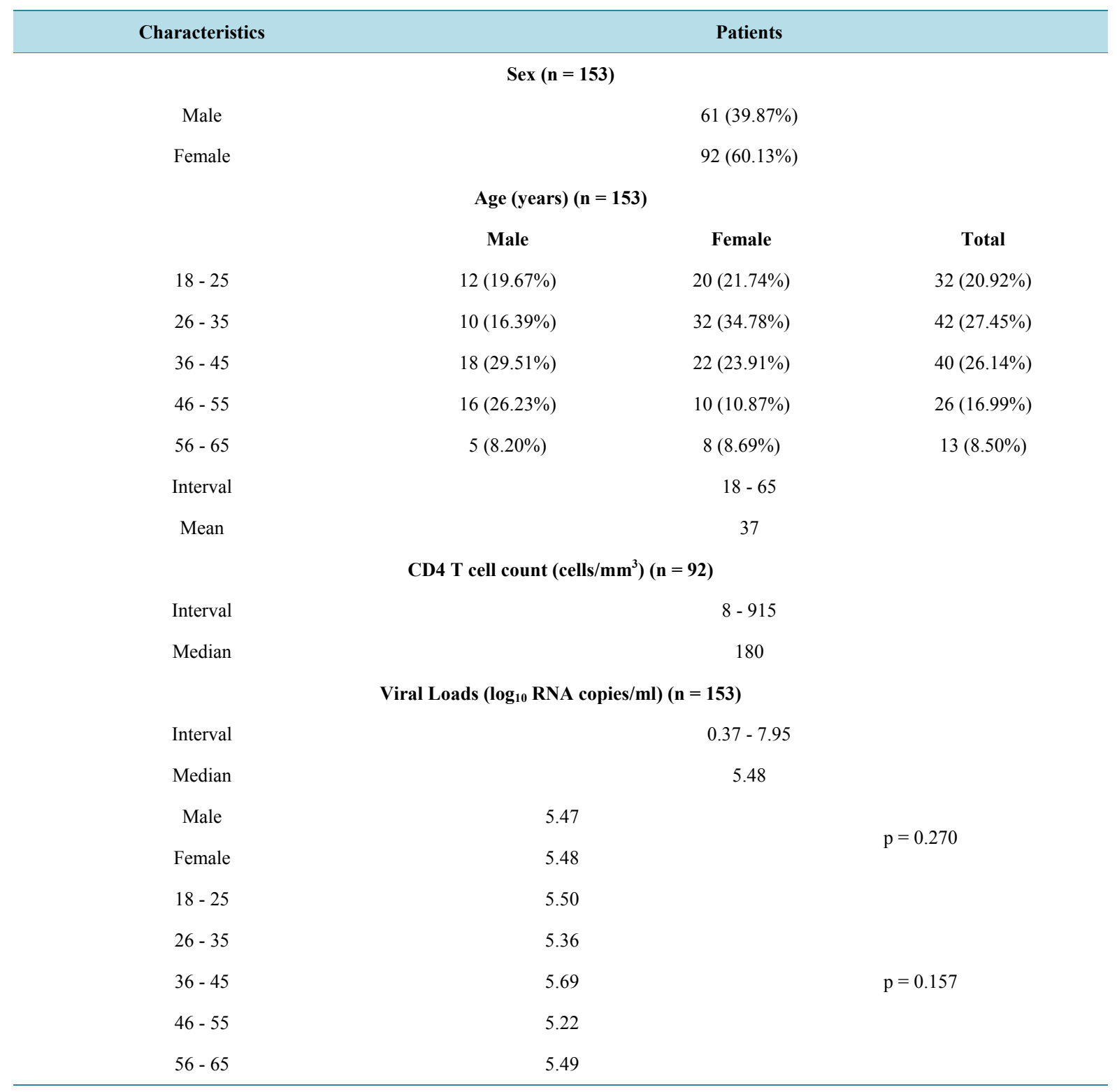

$49(32.0 \%)$ had a VL from 3.0 to $5.00 \log _{10}$; and $7(4.6 \%)$ had a VL less than $3.0 \log _{10}$. Differences VLs compared to different age groups and types are not significant (Table 1).

\section{Discussion}

The aim of this study was to determine the virological profiles of patients infected with HIV eligible for Antiretroviral Therapy (ART) in Kinshasa. Our sample consisted of 92 women (60.1\%) and 63 men (39.9\%), a sex ratio $\mathrm{M} / \mathrm{F}$ of 0.68 . These observations in relation to the gender difference are similar to that published by the national program that gives a sex ratio M/F below 1.00 [1]. Various other studies have also published M/F sex ratios that tend to feminize HIV infection in our environment [10]-[12]. The predominance of female patients infected with HIV in Kinshasa, Democratic Republic of Congo and in Sub-Saharan Africa can be explained by early sexual intercourse, the lack of information and education on sexuality, life and HIV, and sexual risky behavior [13].

The age interval most presented is that of 26 to 35 years with 42 patients $(27.5 \%)$, followed by those 36 to 45 
years $(26.2 \%)$ and 18 to 25 years $(20.9 \%)$. This predominant age group is the active mass of the population. This population is most active in terms of resource production (labor), but also in terms of sexual activities. These results are similar to those reported in various local literatures [10]-[12].

All patients in this study were eligible for ART in their respective centers. In agreement with the clinical and immunological criteria, clinicians decide the initiation of ART in monitoring patient. Clinically, starting treatment is justifiable for all patients because they are all in advanced stage of HIV infection $(91.5 \%$ clinical stage 3 and $8.5 \%$ clinical stage 4$)$. The CD4 T cells counts were performed for 91 patients (59.5\%). Although recommended by the national program, the CD4 count is not done routinely in all centers [7]. For these patients with the results of CD4, $79(86.8 \%)$ have values less than $500 \mathrm{cells} / \mathrm{mm}^{3}$. For patients who had values greater than 500 cells $/ \mathrm{mm}^{3}$, the clinical criterion had predominance for initiation to treatment.

The median Viral Loads (VL) of patients included in the study is of $5.48 \log _{10}$ RNA copies $/ \mathrm{ml}$. The minimum and maximum values of the VLs are respectively $0.37 \log _{10}$ and $7.95 \log _{10}$ RNA copies/ml. Ninety-seven patients $(63.4 \%)$ have a VL higher than 100,000 RNA copies $/ \mathrm{ml}$ or $5.0 \log _{10}$ RNA copies $/ \mathrm{ml}$; $49(32.0 \%)$ have a VL between $3.0 \log _{10}$ and $5.00 \log _{10}$ RNA copies $/ \mathrm{ml}$; and 7 (4.6\%) have a VL under $3.0 \log _{10}$ RNA copies $/ \mathrm{ml}$. Differences VLs in age groups and with respect to gender were not significant; the age group 36 to 45 years has the highest median VL $\left(5.69 \log _{10}\right.$ RNA copies $\left./ \mathrm{ml}\right)$, while the group of 46 to 55 years has the lowest median (5.22 $\log _{10}$ RNA copies/ml). Several studies have shown that VL higher than 100,000 RNA copies $/ \mathrm{ml}\left(5.0 \log _{10}\right.$ RNA copies $/ \mathrm{ml}$ ) is a poor prognosis for treatment regardless of CD4 baseline [14]-[16]. In this case, $63.4 \%$ of patients started ART with a poor prognosis, a program that could lead very quickly to treatment failure or to ever higher VL after 6 months of ART. The rest of the patients (36.6\%) started ART within standards for a correct prognosis. It is therefore important for the clinician to have the results of the VL at initiation of ART to better guide treatment for a correct prognosis [4]. Hence, the importance of implementing VL assays accessible to all.

\section{Conclusion}

The majority of patients (63.4\%) in Kinshasa begin antiretroviral treatment with a poor prognosis. The Viral Loads are usually very high in these patients and CD4 quite collapsed. Indeed, the median value of CD4 for the patients is $180 \mathrm{cells} / \mathrm{mm}^{3}$ for the population, while the mean value of Viral Load is $5.48 \log _{10} \mathrm{RNA}$ copies $/ \mathrm{ml}$. The Viral Load should also be used as a criterion for starting treatment for countries with limited resources in order to achieve the goals of universal access to treatment for HIV.

\section{References}

[1] Programme National de Lutte contre le VIH/SIDA et les Infections Sexuellement Transmissible (PNLS), Ministère de la Santé Publique, République Démocratique du Congo (RDC). Rapport Annuel. 2009 à 2012.

[2] Programme National de Lutte contre le VIH/SIDA et les Infections Sexuellement Transmissible (PNLS), Ministère de la Santé Publique, République Démocratique du Congo (RDC). Guide National de Prise en Charge de l'Infection à VIH en RDC. Version révisé 2013.

[3] World Health Organization. Antiretroviral Therapy for HIV Infection in Adults and Adolescents, Recommendations for a Public Health Approach. Revision 2010. http://whqlibdoc.who.int/publications/2010/9789241599764 eng.pdf

[4] Ingole, N.A., Kukreja, S.M. and Mehta, P.R. (2011) Role of HIV-1 Viral Load in Initiating Antiretroviral Therapy. World Journal of AIDS, 1, 149-154. http://dx.doi.org/10.4236/wja.2011.14022

[5] Kamangu, N.E., Kawila, M.E., Mukumbi, H. and Mvumbi, L.G. (2012) Estimated Rates of Treatment Failure in FirstLine Antiretroviral Treatment in Kinshasa: Case of the ACS AMO-Congo. International Journal of Collaborative Research on Internal Medicine and Public Health (IJCRIMPH), 4, 885-891.

[6] Calmy, A., Ford, N., Hirschel, B., Reynolds, S.J., Lynen, L., Goemaere, E., De la Vega, F.G., Perrin, L. and Rodriguez, W. (2007) HIV Viral Load Monitoring in Resource-Limited Regions: Optional or Necessary? Clinical Infectious Diseases, 44, 128-134. http://dx.doi.org/10.1086/510073

[7] Kamangu, N.E., Kalala, N.H. and Mesia, K.G. (2012) Profile of Antiretroviral Treatment Centers in Kinshasa, Democratic Republic of Congo [Poster 388]. Proceedings of the 1st International African Society of Laboratory Medicine (ASLM) Conference, Cape Town, 1-7 December 2012, 377.

[8] Kamangu, N.E., Adawaye, C., Boreux, R., Kalala, L.R., Mvumbi, L.G., Vaira, D. and Hayette, M.P. (2014) Mise en place d'une PCR Quantitative Temps Réel pour la détermination de la Charge Virale VIH à Kinshasa. Journal de RechercheBioMédicale, 1, 7-12. 
[9] Kamangu, N.E., Chatte, A., Boreux, R., Kalala, L.R., Mvumbi, L.G., De Mol, P., Vaira, D. and Hayette, M.P. (2014) Implementation of an In-House Quantitative Real-Time PCR for Determination of HIV Viral Load in Kinshasa. Open Access Library Journal, 1, e855. http://dx.doi.org/10.4236/oalib.1100855

[10] Desclaux, A. and Desgrées du Lou, A. (2006) Les Femmes Africaines face à l'épidémie du SIDA. Population etSociétés, 428, 1-4.

[11] Karier, R. and Marissa, Y. (2009) Renforcement de l'intégration des services de planification familiale et de traitement du VIH. PRB USAID.

[12] Kamangu, N.E., Situakibanza, N.H., Mvumbi, L.G., Kakudji, I.L., Tshienda, T.D. and Mesia, K.G. (2012) Infections Opportunistes chez les Personnes Vivant avec le VIH suivi à l'Hôpital Militaire de Référence de Kinshasa (Camp Kokolo). Revue Congolaise des Sciences, 1, 66-76.

[13] ONUSIDA (2006) Rapport sur l'épidémiologie Mondiale du SIDA. ONUSIDA, Genève, 3-4.

[14] Wateba, I.N., Patassi, A.A., Balaka, A. and Tidjani, O. (2013) Viral Characteristic of HIV Infected Patients Naif of Anti-Retroviral Therapy with CD4+ T Lymphocytes Rate Greater than 350 per Microliter of Blood in Lomé, Togo. World Journal of AIDS, 3, 364-366. http://dx.doi.org/10.4236/wja.2013.34047

[15] Egger, M., May, M. and Chêne, G. (2002) Prognosis of HIV-1-Infected Patients Starting Highly Active Therapy: A Collaborative Analysis of Prospective Studies. The Lancet, 360, 119-129. http://dx.doi.org/10.1016/S0140-6736(02)09411-4

[16] Phair, J.P., Mellors, J.W., Detels, R., Margolick, J.B. and Munoz, A. (2002) Virologic and Immunologic Values Allowing Safe Deferral of Antiretroviral Therapy. AIDS, 16, 2455-2459.

http://dx.doi.org/10.1097/00002030-200212060-00011 